\title{
Burkholderia sediminicola sp. nov., isolated from freshwater sediment
}

\author{
Ju Hyoung Lim, Sang-Hoon Baek and Sung-Taik Lee
}

Correspondence

Sung-Taik Lee

e_stlee@kaist.ac.kr

\author{
Environmental and Molecular Microbiology Lab., Department of Biological Sciences, Korea \\ Advanced Institute of Science and Technology (KAIST), 335 Gwahangno (373-1 Guseong-dong), \\ Yuseong-gu, Daejeon 305-701, Republic of Korea
}

\begin{abstract}
A Gram-negative, motile and rod-shaped bacterium, designated HU2-65W ${ }^{\top}$, was isolated from freshwater sediment. The strain possessed ubiquinone 8 as the predominant isoprenoid quinone and contained major amounts of $\omega 7$-cis-octadecenoic acid and hexadecanoic acid in its cell envelope, which are properties shared by members of the genus Burkholderia. On the basis of 16S rRNA gene sequence similarity, strain $\mathrm{HU}_{2}-65 \mathrm{~W}^{\top}$ was most closely related to the type strain of Burkholderia xenovorans (98.4\%). The DNA G+C content of strain HU2-65W ${ }^{\top}$ was $61.2 \mathrm{~mol} \%$, and DNA-DNA relatedness values to type strains of closely related species were found to be much lower than $70 \%$, indicating that the strain represents a separate genomic species within the genus Burkholderia. Strain $\mathrm{HU} 2-65 \mathrm{~W}^{\top}$ was also differentiated from other species of the genus by physiological and biochemical characteristics. Consequently, strain HU2-65W $\mathrm{W}^{\top}$ is considered to represent a single, novel species of the genus Burkholderia, for which the name Burkholderia sediminicola sp. nov. is proposed, with the type strain $\mathrm{HU}_{2}-65 \mathrm{~W}^{\top}$ $\left(=\right.$ KCTC $22086^{\top}=$ LMG $\left.24238^{\top}\right)$.
\end{abstract}

The genus Burkholderia has been recognized as a group with great diversity and at present contains more than 40 species with validly published names, which have been isolated from a wide array of ecological niches, ranging from soil to animal clinical samples (Coenye \& Vandamme, 2003). During attempts to investigate the culturability and diversity of bacteria in freshwater sediment, an aerobic bacterium, designated $\mathrm{HU} 2-65 \mathrm{~W}^{\mathrm{T}}$, was isolated from an extinction-culture plate and was then subjected to taxonomic studies. The genotypic, phenotypic and chemotaxonomic traits provided evidence that strain HU2-65W ${ }^{\mathrm{T}}$ belongs to a novel species in the genus Burkholderia.

Sediment samples were collected from Lake Hakha $\left(36^{\circ} 16^{\prime}\right.$ $60^{\prime \prime} \mathrm{N} 127^{\circ} 18^{\prime} 32^{\prime \prime} \mathrm{E}$ ), a typical freshwater lake in South Korea. The sediment was homogenized by using a Nissei homogenizer and the suspension was serially diluted with freshwater medium, which was collected at the same sampling site the day prior to sampling and was then filtersterilized. Dilution-to-extinction arrays (Button et al., 1993) were made in 96-well plates to reach a cell concentration of 1.1 cells per volume according to the total count in the sediment sample. The plates were incubated in a GasPak EZ anaerobic container (BD) for 3 months at ambient temperature in a cycle consisting of

Abbreviation: PHA, polyhydroxyalkanoate.

The GenBank/EMBL/DDBJ accession number for the 16S rRNA gene sequence of Burkholderia sediminicola HU2-65W' is EU035613.
$12 \mathrm{~h}$ light and $12 \mathrm{~h}$ darkness. In order to detect nonturbidity growth in extinction wells (Martens-Habbena \& Sass, 2006), portions of cell suspensions were stained with $4^{\prime}, 6^{\prime}$-diamidino-2-phenylindole (DAPI) and fluorescence was measured by a microplate reader Flx 800 (BioTek). One single colony was isolated on a 1/10 R2A agar plate to which bacterial suspension was transferred from a well showing bacterial growth. The isolate was then routinely propagated aerobically on R2A agar at $28{ }^{\circ} \mathrm{C}$ for 2 days.

Colonies were directly applied to $16 \mathrm{~S}$ rRNA gene PCR and amplified fragments were then sequenced using the primers 9F (Stackebrandt \& Liesack, 1993), 341F (Muyzer et al., 1993), 536R and 907F (Lane et al., 1985), 1100R (Lane, 1991) and 1512R (Weisburg et al., 1991). The 16S rRNA gene sequence of strain HU2-65W $\mathrm{W}^{\mathrm{T}}$ was compared with all $16 \mathrm{~S}$ rRNA gene sequences available in GenBank, and alignment of sequences was carried out with the CLUSTAL_X program (Thompson et al., 1997). Gaps at the $5^{\prime}$ and $3^{\prime}$ ends and ambiguous bases were removed from the alignment using the BioEdit software (Hall, 1999). DNA for determination of base composition and hybridization analysis was extracted and purified using the Qiagen Genomic-tip system 100/G. Enzymic degradation of DNA into nucleosides was carried out as described previously (Mesbah et al., 1989). DNA-DNA hybridization was performed fluorometrically by the method of Ezaki et al. (1989) in black MaxiSorp FluoroNunc module plates (Nunc). Before hybridization, biotinylated probe DNAs were sheared by ultrasonication using a Bioruptor 
(Cosmo). Hybridization was performed at $49.4{ }^{\circ} \mathrm{C}$ in the presence of $50 \%(\mathrm{v} / \mathrm{v})$ formamide with the ionic strength of $0.3 \mathrm{M} \mathrm{NaCl}$ and carried out reciprocally with five replications per sample.

Cell morphology and motility were examined by phasecontrast microscopy. Catalase and oxidase activities were determined by using standard methods (Cowan \& Steel, 1965). The Gram reaction was performed according to Buck (1982). Substrate assimilation and some biochemical characters were determined using API 32GN, API 20NE and API ZYM galleries (bioMérieux) according to the manufacturer's protocol. Polyhydroxyalkanoate (PHA) accumulation was tested by viable-colony staining (Spiekermann et al., 1999) under nitrogen-depletion conditions supplemented with $2 \%(\mathrm{w} / \mathrm{v})$ glucose as an excess carbon source (Wieczorek et al., 1996). Presence of the PHA synthase gene was investigated by amplifying an internal region of phaC with the primer set I-179L/I-179R (Solaiman et al., 2000). Amylase and DNase activities were detected on starch agar and DNase test agar (Difco), respectively. Carbohydrate oxidation/fermentation $(\mathrm{O} / \mathrm{F})$ test was performed according to Hugh \& Leifson (1953). Antibiotic susceptibility was evaluated by MIC determination (Andrews, 2001), whereby 12 successive dilutions of antibiotics in R2A broth were used. Isoprenoid quinones were determined as described previously (Komagata \& Suzuki, 1987) using Sep-Pak Vac silica cartridges (Waters). For quantitative analysis of cellular fatty acid compositions, cells were harvested after $24 \mathrm{~h}$ incubation at $28{ }^{\circ} \mathrm{C}$ on TSA (Difco), which was based on the culture conditions used for closely related Burkholderia strains (Coenye et al., 2001; Goris et al., 2002, 2004), and cellular fatty acid methyl esters were prepared and identified following the protocol of the Sherlock Microbial Identification System (MIDI). All phenotypic tests described above were performed at least twice with 2 days incubation, unless otherwise specified.

The 16S rRNA gene sequence of strain HU2-65W ${ }^{\mathrm{T}}$ (1473 bp) showed the highest similarity to members of the genus Burkholderia; the type strains of Burkholderia xenovorans, Burkholderia bryophila (Vandamme et al., 2007), Burkholderia fungorum and Burkholderia terricola showed 98.4, 98.3, 98.2 and $98.1 \%$ similarity, respectively, to strain $\mathrm{HU} 2-65 \mathrm{~W}^{\mathrm{T}}$. In the phylogenetic tree constructed by the neighbour-joining algorithm (Saitou \& Nei, 1987), strain HU2-65 $\mathrm{W}^{\mathrm{T}}$ formed a coherent cluster within the Burkholderia graminis group (Goris et al., 2004) (Fig. 1). The DNA G+C content of strain $\mathrm{HU} 2-65 \mathrm{~W}^{\mathrm{T}}$ was $61.2 \mathrm{~mol} \%$, which is very similar to values for closely related species. DNA-DNA relatedness values in reciprocal hybridizations were much lower than $70 \%$ between strain HU2- $65 \mathrm{~W}^{\mathrm{T}}$ and the following closely related members of the genus Burkholderia: B. xenovorans KACC $12026^{\mathrm{T}}$ (43 and $47 \%$, reciprocally), B. bryophila LMG $23644^{\mathrm{T}}$ (33 and $34 \%)$, B. fungorum KACC $12023^{\mathrm{T}}$ (49 and $\left.23 \%\right), B$. terricola KACC $12025^{\mathrm{T}}(41 \%)$ and Burkholderia ginsengisoli KCTC $12389^{\mathrm{T}}$ (47 and 56\%), indicating that strain HU2$65 \mathrm{~W}^{\mathrm{T}}$ represents a separate genomic species belonging to the genus Burkholderia.

Morphological, physiological and biochemical characteristics of strain $\mathrm{HU} 2-65 \mathrm{~W}^{\mathrm{T}}$ were consistent with its classification within the genus Burkholderia (Table 1). Cells were Gram-negative, motile, slightly curved rods and the strain grew optimally at $25-30{ }^{\circ} \mathrm{C}$ and $\mathrm{pH}$. The strain was able to accumulate PHA on a nitrogen-depletion medium supplemented with $2 \%(\mathrm{w} / \mathrm{v})$ glucose, which was confirmed by the presence of the phaC gene, of which a $540 \mathrm{bp}$ internal region (Solaiman et al., 2000) was amplified and sequenced (GenBank accession no. EU035614). Resistance up to $100 \mu \mathrm{g}$ ampicillin $\mathrm{ml}^{-1}$ was observed, but the strain did not grow with kanamycin, streptomycin or tetracycline, even at concentrations of $1 \mu \mathrm{g}$ $\mathrm{ml}^{-1}$. Strain HU2-65W $\mathrm{W}^{\mathrm{T}}$ was unable to assimilate $\mathrm{L}^{-}$ arabinose, as found previously in B. xenovorans strains (Goris et al., 2004). The strain possessed ubiquinone Q-8 as the predominant isoprenoid quinone, which is typical of members of the genus Burkholderia. The high levels of $\omega 7$ cis-octadecenoic acid $\left(\mathrm{C}_{18: 1} \omega 7 \mathrm{c}\right)$ and hexadecanoic acid $\left(\mathrm{C}_{16: 0}\right)$ were in good agreement with cellular fatty acid

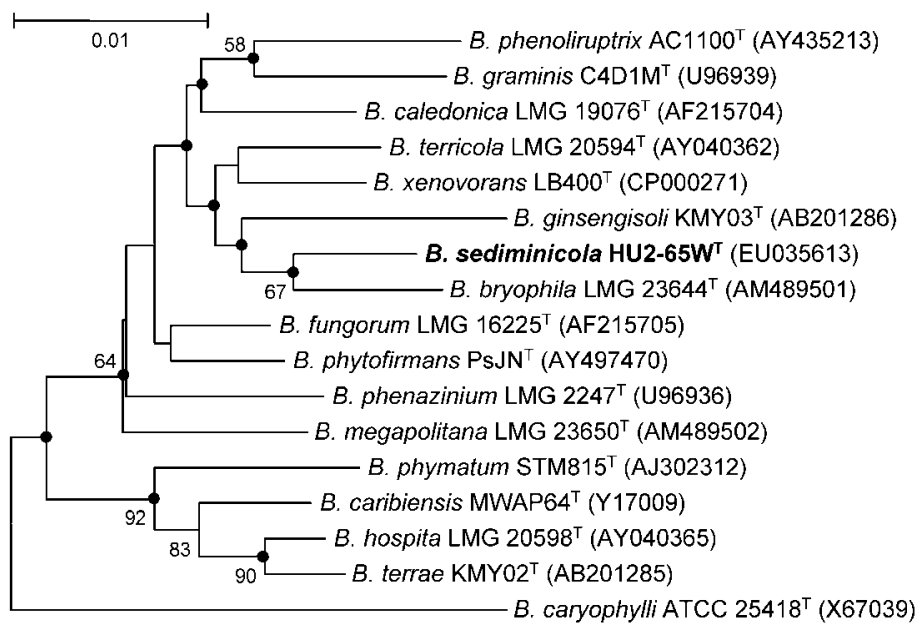

Fig. 1. Neighbour-joining tree showing relationships between strain $\mathrm{HU} 2-65 \mathrm{~W}^{\top}$ and closely related taxa belonging to the genus Burkholderia. Bootstrap values of $50 \%$ or more (using 1000 replications) are indicated at branch points. Filled circles indicate that the corresponding nodes were also recovered in maximum-parsimony trees. Accession numbers are shown in parentheses. Bar, 0.01 expected substitutions per nucleotide position. 
Table 1. Phenotypic characteristics that distinguish strain $\mathrm{HU} 2-65 \mathrm{~W}^{\top}$ from closely related Burkholderia species

Taxa: 1, strain HU2-65W $\mathrm{W}^{\mathrm{T}}$; 2, B. xenovorans (3 strains included); 3, B. bryophila (14); 4, B. fungorum (9); 5, B. terricola (17); 6, B. ginsengisoli (1). Data for reference species were taken from Coenye et al. (2001, 2004), Fain \& Haddock (2001), Goris et al. (2002, 2004), Lim et al. (2003), Kim et al. (2006) and Vandamme et al. (2007). The following features are present in all strains: growth at $30{ }^{\circ} \mathrm{C}$, activity of acid and alkaline phosphatase and leucine arylamidase and assimilation of $N$-acetyl-D-glucosamine, D-glucose, DL-lactate and mannitol. The following features are absent in all strains: growth at $\mathrm{NaCl}$ concentrations above $3 \%(\mathrm{w} / \mathrm{v})$ and activity of chymotrypsin, $\alpha$-fucosidase, $\alpha$-galactosidase, $\alpha$-glucosidase, $\alpha$-mannosidase, trypsin and tryptophanase. +, All strains positive; -, all strains negative; $\mathrm{v}(+)$, strain dependent, positive for type strain; $\mathrm{v}(-)$, strain dependent, negative for type strain; ND, no data available.

\begin{tabular}{|c|c|c|c|c|c|c|}
\hline Characteristic & 1 & 2 & 3 & 4 & 5 & 6 \\
\hline Nitrate reduction & - & $\mathrm{V}(-)$ & - & + & + & - \\
\hline Growth at $37{ }^{\circ} \mathrm{C}$ & - & $\mathrm{V}(-)$ & - & + & $\mathrm{V}(+)$ & + \\
\hline Acid production in $\mathrm{O} / \mathrm{F}$ medium with $\mathrm{D}$-glucose & - & - & - & + & $\mathrm{v}(+)$ & - \\
\hline Activity of $\mathrm{C}_{14}$-lipase & + & - & - & $\mathrm{V}(-)$ & - & - \\
\hline \multicolumn{7}{|l|}{ Assimilation of: } \\
\hline D-Gluconate & - & + & + & + & + & + \\
\hline D-Mannose & - & + & + & + & + & + \\
\hline \multicolumn{7}{|l|}{ Major fatty acid composition $(\%)^{\star}$} \\
\hline $\mathrm{C}_{16: 0}$ & 20.8 & 18.2 & $\mathrm{ND}$ & $14.7 \pm 0.9$ & $14.3 \pm 1.3$ & 16.1 \\
\hline $\mathrm{C}_{17: 0}$ cyclo & 7.0 & 5.1 & $\mathrm{ND}$ & $5.1 \pm 1.6$ & $14.0 \pm 5.2$ & 24.9 \\
\hline $\mathrm{C}_{19: 0}$ cyclo $\omega 8 \mathrm{c}$ & 2.9 & 3.6 & $\mathrm{ND}$ & $2.5 \pm 0.7$ & $5.5 \pm 3.0$ & 15.1 \\
\hline
\end{tabular}

${ }^{*}$ Some values are represented as means $\pm \mathrm{SD}$.

†Composed of $\mathrm{C}_{18: 1} \omega 7 \mathrm{c} / \omega 9 \mathrm{t} / \omega 12 t$ and/or $\mathrm{C}_{18: 1} \omega 7 \mathrm{c} / \omega 9 \mathrm{c} / \omega 12 t$.

\$Composed of $\mathrm{C}_{12: 0}$ ALDE with ECL 10.928/iso- $\mathrm{C}_{16: 1} \mathrm{I}_{\mathrm{C}} \mathrm{C}_{14: 0} 3-\mathrm{OH}$.

$\S$ Composed of iso- $\mathrm{C}_{15: 0} 2-\mathrm{OH} / \mathrm{C}_{16: 1} \omega 7 c$.

profiles of previously described Burkholderia species. The presence of 3-hydroxyhexadecanoic acid $\left(\mathrm{C}_{16: 0} 3-\mathrm{OH}\right)$ was also consistent with a unique characteristic shared by members of the genus Burkholderia (Gillis et al., 1995). Phenotypic characteristics of strain HU2-65 $\mathrm{W}^{\mathrm{T}}$ and those of the most closely related species are summarized in Table 1.

The genotypic and phenotypic data given above clearly demonstrate that strain HU2-65W $\mathrm{W}^{\mathrm{T}}$ represents a novel Burkholderia species, for which we propose the name Burkholderia sediminicola sp. nov.

\section{Description of Burkholderia sediminicola sp. nov.}

Burkholderia sediminicola (se.di.mi.ni.co'la. L. n. sedimen, -inis sediment; L. suff. -cola inhabitant, dweller; N.L. n. sediminicola sediment-dweller, referring to the source of the type strain).

Rod-like cells occur as single units or in pairs with rounded ends and are $0.6-1.4 \mu \mathrm{m}$ long by $0.3-0.5 \mu \mathrm{m}$ wide. Colonies grown on R2A for $36 \mathrm{~h}$ are circular and convex with an entire margin, $0.6-1 \mathrm{~mm}$ in diameter, translucent and creamy white in colour. No slime formation is observed. Temperature range for growth is $15-30{ }^{\circ} \mathrm{C}$; no growth occurs at $42^{\circ} \mathrm{C}$. Cells grow at $\mathrm{pH} 6.0-8.0$ and are unable to denitrify. Best growth is obtained without $\mathrm{NaCl}$, but growth is possible in the presence of $1.5 \%(\mathrm{w} / \mathrm{v}) \mathrm{NaCl}$. None of D-fructose, D-glucose, maltose or D-xylose is oxidized or fermented in $\mathrm{O} / \mathrm{F}$ medium. Tests for catalase, $\mathrm{C}_{4}$-esterase, $\mathrm{C}_{8}$-ester lipase, naphthol-AS-BI-phosphohydrolase and oxidase activities are positive. Tests for amylase, arginine dihydrolase, cystine arylamidase, DNase, gelatinase, $N$-acetyl- $\beta$-glucosaminidase, $\beta$-glucosidase, $\beta$-glucuronidase, urease and valine arylamidase activities are negative. $\beta$-Galactosidase activity is substrate dependent, i.e. 4 -nitrophenyl $\beta$-D-galactopyranoside is hydrolysed but 2 -naphthyl $\beta$-D-galactopyranoside is not. Carbenicillin, cephalothin, lincomycin, penicillin $G$ and rifampicin do not inhibit growth at concentrations of up to $100 \mu \mathrm{g} \mathrm{ml}{ }^{-1}$. Resistance is shown to up to $50 \mu \mathrm{g}$ novobiocin, $20 \mu \mathrm{g}$ hygromycin $\mathrm{B}, 15 \mu \mathrm{g}$ oleandomycin or $5 \mu \mathrm{g}$ chloramphenicol $\mathrm{ml}^{-1}$, but growth is inhibited by erythromycin, gentamicin or neomycin even at concentrations of $1 \mu \mathrm{g} \mathrm{ml}^{-1}$. L-Alanine, citrate, L-fucose, histidine, 4hydroxybenzoate, 3-hydroxybutyrate, 2-ketogluconate, malate, phenylacetate, L-proline, D-ribose and D-sorbitol are utilized as sole carbon sources; acetate, adipate, caprate, 
glycogen, 3-hydroxybenzoate, inositol, itaconate, 5-ketogluconate, malonate, maltose, melibiose, propionate, rhamnose, salicin, L-serine, suberate, sucrose and valerate are not. The following fatty acids are present in relatively small amounts: $\mathrm{C}_{16: 0} 3-\mathrm{OH}(6.2 \%), \mathrm{C}_{16: 0} 2-\mathrm{OH}(2.2 \%)$, $\mathrm{C}_{14: 0}(1.4 \%), \mathrm{C}_{16: 1} 2-\mathrm{OH}(1.3 \%), \mathrm{C}_{18: 1} 2-\mathrm{OH}(0.8 \%)$, $\mathrm{C}_{18: 0}(0.7 \%)$ and $\mathrm{C}_{18: 1} \omega 5 c(0.5 \%)$. Additional characteristics are listed in Table 1 and described elsewhere in the text.

The type strain is HU2-65W $\mathrm{W}^{\mathrm{T}}\left(=\mathrm{KCTC} 22086^{\mathrm{T}}=\mathrm{LMG}\right.$ $24238^{\mathrm{T}}$ ), which was isolated from freshwater sediment.

\section{Acknowledgements}

The authors wish to thank Dr Kwang Kyu Kim, Korea Research Institute of Bioscience and Biotechnology (KRIBB), and Dr Jean Euzéby, Ecole Nationale Vétérinaire, for etymological advice. This work was supported by the 21C Frontier Microbial Genomics and Application Center Program, Ministry of Science and Technology (grant MG05-0101-4-0), Republic of Korea.

\section{References}

Andrews, J. M. (2001). Determination of minimum inhibitory concentrations. J Antimicrob Chemother 48, 5-16.

Buck, J. D. (1982). Nonstaining (KOH) method for determination of Gram reactions of marine bacteria. Appl Environ Microbiol 44, 992-993.

Button, D. K., Schut, F., Quang, P., Martin, R. \& Robertson, B. R. (1993). Viability and isolation of marine bacteria by dilution culture: theory, procedures, and initial results. Appl Environ Microbiol 59, 881-891.

Coenye, T. \& Vandamme, P. (2003). Diversity and significance of Burkholderia species occupying diverse ecological niches. Environ Microbiol 5, 719-729.

Coenye, T., Laevens, S., Willems, A., Ohlén, M., Hannant, W., Govan, J. R., Gillis, M., Falsen, E. \& Vandamme, P. (2001). Burkholderia fungorum sp. nov. and Burkholderia caledonica sp. nov., two new species isolated from the environment, animals and human clinical samples. Int J Syst Evol Microbiol 51, 1099-1107.

Coenye, T., Henry, D., Speert, D. P. \& Vandamme, P. (2004). Burkholderia phenoliruptrix sp. nov., to accommodate the 2,4,5trichlorophenoxyacetic acid and halophenol-degrading strain AC1100. Syst Appl Microbiol 27, 623-627.

Cowan, S. T. \& Steel, K. J. (1965). Manual for the Identification of Medical Bacteria. London: Cambridge University Press.

Ezaki, T., Hashimoto, Y. \& Yabuuchi, E. (1989). Fluorometric deoxyribonucleic acid-deoxyribonucleic acid hybridization in microdilution wells as an alternative to membrane filter hybridization in which radioisotopes are used to determine genetic relatedness among bacterial strains. Int J Syst Bacteriol 39, 224-229.

Fain, M. G. \& Haddock, J. D. (2001). Phenotypic and phylogenetic characterization of Burkholderia (Pseudomonas) sp. strain LB400. Curr Microbiol 42, 269-275.

Gillis, M., Van Van, T., Bardin, R., Goor, M., Hebbar, P., Willems, A., Segers, P., Kersters, K., Heulin, T. \& other authors (1995). Polyphasic taxonomy in the genus Burkholderia leading to an emended description of the genus and proposition of Burkholderia vietnamiensis sp. nov. for $\mathrm{N}_{2}$-fixing isolates from rice in Vietnam. Int $J$ Syst Bacteriol 45, 274-289.
Goris, J., Dejonghe, W., Falsen, E., De Clerck, E., Geeraerts, B., Willems, A., Top, E. M., Vandamme, P. \& De Vos, P. (2002). Diversity of transconjugants that acquired plasmid pJP4 or pEMT1 after inoculation of a donor strain in the A- and B-horizon of an agricultural soil and description of Burkholderia hospita sp. nov. and Burkholderia terricola sp. nov. Syst Appl Microbiol 25, 340-352.

Goris, J., De Vos, P., Caballero-Mellado, J., Park, J., Falsen, E., Quensen, J. F., III, Tiedje, J. M. \& Vandamme, P. (2004). Classification of the biphenyl- and polychlorinated biphenyl-degrading strain $\mathrm{LB} 400^{\mathrm{T}}$ and relatives as Burkholderia xenovorans sp. nov. Int J Syst Evol Microbiol 54, 1677-1681.

Hall, T. A. (1999). BioEdit: a user-friendly biological sequence alignment editor and analysis program for Windows 95/98/NT. Nucleic Acids Symp Ser 41, 95-98.

Hugh, R. \& Leifson, E. (1953). The taxonomic significance of fermentative versus oxidative metabolism of carbohydrates by various Gram negative bacteria. J Bacteriol 66, 24-26.

Kim, H.-B., Park, M.-J., Yang, H.-C., An, D.-S., Jin, H.-Z. \& Yang, D.-C. (2006). Burkholderia ginsengisoli sp. nov., a $\beta$-glucosidase-producing bacterium isolated from soil of a ginseng field. Int J Syst Evol Microbiol 56, 2529-2533.

Komagata, K. \& Suzuki, K. (1987). Lipid and cell wall analysis in bacterial systematics. Methods Microbiol 19, 161-207.

Lane, D. J. (1991). 16S/23S rRNA sequencing. In Nucleic Acid Techniques in Bacterial Systematics, pp. 115-175. Edited by E. Stackebrandt \& M. Goodfellow. Chichester: Wiley.

Lane, D. J., Pace, B., Olsen, G. J., Stahl, D. A., Sogin, M. L. \& Pace, N. R. (1985). Rapid determination of $16 \mathrm{~S}$ ribosomal RNA sequences for phylogenetic analyses. Proc Natl Acad Sci U S A 82, 6955-6959.

Lim, Y. W., Baik, K. S., Han, S. K., Kim, S. B. \& Bae, K. S. (2003). Burkholderia sordidicola sp. nov., isolated from the white-rot fungus Phanerochaete sordida. Int J Syst Evol Microbiol 53, 1631-1636.

Martens-Habbena, W. \& Sass, H. (2006). Sensitive determination of microbial growth by nucleic acid staining in aqueous suspension. Appl Environ Microbiol 72, 87-95.

Mesbah, M., Premachandran, U. \& Whitman, W. B. (1989). Precise measurement of the $\mathrm{G}+\mathrm{C}$ content of deoxyribonucleic acid by high-performance liquid chromatography. Int J Syst Bacteriol 39, 159-167.

Muyzer, G., de Waal, E. C. \& Uitterlinden, A. G. (1993). Profiling of complex microbial populations by denaturing gradient gel electrophoresis analysis of polymerase chain reaction-amplified genes coding for $16 S$ rRNA. Appl Environ Microbiol 59, 695-700.

Saitou, N. \& Nei, M. (1987). The neighbor-joining method: a new method for reconstructing phylogenetic trees. Mol Biol Evol 4, 406-425.

Solaiman, D. K., Ashby, R. D. \& Foglia, T. A. (2000). Rapid and specific identification of medium-chain-length polyhydroxyalkanoate synthase gene by polymerase chain reaction. Appl Microbiol Biotechnol 53, 690-694.

Spiekermann, P., Rehm, B. H. A., Kalscheuer, R., Baumeister, D. \& Steinbüchel, A. (1999). A sensitive, viable-colony staining method using Nile red for direct screening of bacteria that accumulate polyhydroxyalkanoic acids and other lipid storage compounds. Arch Microbiol 171, 73-80.

Stackebrandt, E. \& Liesack, W. (1993). Nucleic acids and classification. In Handbook of New Bacterial Systematics, pp. 152-189. Edited by M. Goodfellow \& A. G. O'Donnell. London: Academic Press.

Thompson, J. D., Gibson, T. J., Plewniak, F., Jeanmougin, F. \& Higgins, D. G. (1997). The CLUSTAL_X windows interface: flexible 
strategies for multiple sequence alignment aided by quality analysis tools. Nucleic Acids Res 25, 4876-4882.

Vandamme, P., Opelt, K., Knöchel, N., Berg, C., Schönmann, S., De Brandt, E., Eberl, L., Falsen, E. \& Berg, G. (2007). Burkholderia bryophila sp. nov. and Burkholderia megapolitana sp. nov., mossassociated species with antifungal and plant-growth-promoting properties. Int J Syst Evol Microbiol 57, 2228-2235.
Weisburg, W. G., Barns, S. M., Pelletier, D. A. \& Lane, D. J. (1991). 16S ribosomal DNA amplification for phylogenetic study. J Bacteriol 173, 697-703.

Wieczorek, R., Steinbüchel, A. \& Schmidt, B. (1996). Occurrence of polyhydroxyalkanoic acid granule-associated proteins related to the Alcaligenes eutrophus H16 GA24 protein in other bacteria. FEMS Microbiol Lett 135, 23-30. 